\title{
O dużych dziewczynkach i ich małych lalkach - reborn w kulturze ponowoczesnej
}

KEY WORDS

reborn, simulating motherhood, realistic baby like dools, postmodern culture

\begin{abstract}
Zaworska-Nikoniuk Dorota, O dużych dziewczynkach i ich małych lalkach reborn w kulturze ponowoczesnej [Adult Girls and Their Little Dolls - Reborns in the Postmodern Culture]. Kultura - Społeczeństwo - Edukacja nr 1, 2012, Poznań 2012, pp. 157-171, Adam Mickiewicz University Press. ISBN 978-83232-2470-9
\end{abstract}

The article deals with the analysis of the phenomenon of simulating motherhood and fatherhood by playing reborns - realistic baby-like dolls, it describes the process of reborns creation, the intentions of artists who create them and the motives of people who use'artificial children'. The article gives a threefold analysis of the phenomenon: the striving for living in perfect reality that is simulated (based on the concept by J. Baudrillard), acting the play of family life in the magic world of consumption (based on the concept by G. Ritzer) and aiming at collecting experiences, impressions and emotions (based on the concept by Z. Bauman). As an educationalist I am considering the following: may using reborns have a therapeutical and educational aspect and what is their role in the postmodern world.

\section{Rebornowy biznes, czyli dzieci „niemal” jak żywe i ich producentki}

Lalki reborn, czyli odrodzone, gdyż do złudzenia przypominają prawdziwe niemowlęta, pojawiły się po raz pierwszy w latach dziewięćdziesiątych w Stanach Zjednoczonych. Szybko stały się popularne w Kanadzie, Wielkiej Brytanii i Francji. W Polsce zaczęła produkować je Magdalena Binczewska - artystka plastyk z Poznania, która pokazała te niekonwencjonalne „zabawki” (?) na Festiwalu Przedmiotów Artystycznych MTP (Sobańska, 2009), gdzie wzbudziły duże zainteresowanie. Tematyka produkcji i sprzedaży rebornów budzi obecnie wiele kontrowersji. Reborny są tworzone przez plastyków z gotowych części, sprzeda- 
wane na zamówienie, a przyszli użytkownicy (rodzice) mają pewną wizję wyglądu dziecka, której artysta powinien sprostać. Zdarza się, że przynoszą ze sobą zdjęcie dziecka (zabawa rebornami proponowana jest rodzicom, którzy utracili dzieci w wyniku ich śmierci lub płody w wyniku poronienia) lub wnuka w celu wytworzenia jego sztucznej kopii. Prezentowana na filmie dokumentalnym pt. Moje sztuczne dziecko (My Fake Baby), reż Victoria Silver, emitowanym 24 listopada 2008 roku na kanale Zone Club, babcia zamawia „rebornowego wnuka”, by zmniejszyć tęsknotę za chłopcem, którym niegdyś się opiekowała. Gdyby nie fakt, że chodzi o „sztuczne sobowtóry” będące wierną kopią dziecka, można byłoby przypuszczać, iż wytwarzanie rebornów jest procesem klonowania. „Sklonowane” fantazmaty dziecka są niczym innym jak "naturalną symulakrą", czyli „symulakrą opartą na obrazie, naśladownictwie i podrabianiu, harmonijnie, optymistycznie zmierzającą do przywrócenia, odtworzenia bądź ustanowienia natury na wzór Boga" (Baudrillard, 2005: 149). Jak stworzyć taką symulakrę? Sposób jest stosunkowo prosty, choć niewątpliwie wymaga talentu plastycznego i nakładu pracy, gdyż pojedynczy egzemplarz lalki powstaje przez kilka (około czterech) tygodni. Polega na łączeniu gotowych elementów: głowy, tułowia, rąk, nóg i wytapianiu ich w piekarniku, następnie lalce wszczepiane są moherowe włosy, w tułów wstrzykiwany silikon, jest ona pokrywana farbą, by później plastyk mógł dopracowywać szczegóły w zależności od potrzeb (i zasobności portfela) kupującego: żyłki i krosty na twarzy, fałdki i bruzdy, kolor skóry, blizny po pępowinie, paznokcie. Lalka jest tym droższa, im bardziej przypomina niemowlę, a jej ceny wahają się od kilkuset złotych polskich do kilku tysięcy franków czy euro. Najdroższych modeli nie sposób odróżnić od niemowląt: wzrost i waga pokrywa się z gabarytami dziecka, w dotyku nie różnią się od niego, plują, ślinią się, substytut zapachu wytwarzany jest za pomocą olejku eterycznego, zaś odgłos pracy serca za pomocą umieszczonej wewnątrz baterii. Wszak chodzi tu o uzyskanie najdoskonalszej symulakry, w sposób realny oddającej nieistniejącą rzeczywistość rodzicielstwa bezproblemowego. Zapotrzebowanie na „sztuczne dzieci” jest ogromne, czas oczekiwania na realizację zamówienia, jak podaje plastyczka, wynosi przeciętnie pół roku. Tyle trwa proces „narodzin lalki”. W tej swoistej symulacji producenci przejmują ścisłą kontrolę nad językiem, mającą przekonać użytkowniczki i użytkowników rebornowych towarów, iż wraz z ich nabyciem stają się rodzicami. Parafrazując koncepcję Michela Foucaulta, można stwierdzić, że przejmują władzę nad językiem, by narzucić wiedzę o rzeczywistości (Foucault, 2009) konsumenta w tym przypadku, kreując ludzkie potrzeby i pragnienia. Proces produkcji jest tu nazwany „narodzinami”, po których lalka „niemowlę" jest oddawana do adopcji, czyli sprzedawana na aukcjach internetowych Allegro i eBay. Sztuczne dziecko bywa adoptowane (sprzedawane) wraz 
z pępowiną i niemowlęcą wyprawką: kaftanikiem, śpiochami, smoczkiem i jednorazową pieluchą. Trudno ocenić, po co kobiecie „matce” potrzebna jest pępowina, ale można przypuszczać, iż byłaby przydatna, gdyby zechciała symulować też poród. Cena reborna nie wydaje się wysoka, czas produkcji lalki to kilka tygodni, a koszty materiałów (w Polsce sprowadzanych ze Stanów Zjednoczonych) kształtując się w granicach kilkuset złotych. Polscy producenci rebornów deklarują więc, iż zarabiają niewiele... Magdalena Binczewska twierdzi, że na ich produkcji w zasadzie nie zarabia, gdyż zarobek uzyskany ze sprzedaży lalek pokrywa koszty zakupu i sprowadzenia części potrzebnych do wytworzenia nowych towarów. Czy jednak te deklaracje o niskich zarobkach i skomplikowanym procesie narodzin sztucznego dziecka nie są strategią reklamową? W społeczeństwie konsumenckim rozbudzanie potrzeb i pragnień jest strategią niezbędną do przetrwania wytwarzających dobra plastyków. Przy pomocy mediów masowych - w tym przypadku filmów poświęconych rebornom i artykułów prasowych można potrzeby te rozbudzać skuteczniej. Produkujący „sztuczne dzieci” plastycy nie utrzymają się przecież dzięki altruistycznej potrzebie pomocy kobietom, środki do życia może im zapewnić wpajanie użytkownikom (głównie kobietom) przekonania, że wyjątkowe „cuda” natury (?) są produkowane wyłącznie dla potrzebujących albo takich, którzy zaraz na wskutek tej autoreklamy staną się potrzebującymi. Jak pisze J. Baudrillard:

Społeczeństwo konsumpcji charakteryzuje nie tylko obfitość i powszechna dostępność dóbr i usług, lecz również coś o wiele ważniejszego, fakt, że wszystko stanowi usługę. Usługę, że to, co jest przedmiotem konsumpcji, nie prezentuje się nigdy jako zwyczajny produkt, lecz właśnie jako osobista przysługa lub gratyfikacja (Baudrillard, 2006: 216).

W krajach Europy Zachodniej ceny i zapotrzebowanie na reborny kształtują się nieco inaczej, ich produkcja staje się doskonałym sposobem na życie, a na sklonowane nierealne dzieci panuje tu duży popyt. W Stanach Zjednoczonych odbywają się kursy, na których można nauczyć się produkcji lalek, a kończący je plastycy produkują miesięcznie kilkoro „niemowląt”, z których jedno osiąga przeciętną cenę 1000 dolarów, zakładane są też spółki i grupy osób tworzących profesjonalnie lalki reborn. Najdoskonalsi artyści w tym fachu stworzyli stowarzyszenie Artists of Reborn to Cherisch i zauważają, reklamując swój produkt: „[...] zostanie matką to bardzo ekscytujące doświadczenie, ale ta słodka góra radości tak szybko dorasta. Nasze dzieci pozwolą Ci zatrzymać ten cenny czas na zawsze" (Sobańska, 2009). W Polsce jednak - jak deklaruje M. Binczewska - lalkami bawią się przede wszystkim dzieci. W obliczu takiego faktu warto zauważyć, że lalki nie są dopuszczone do sprzedaży; poza zapewnieniami „rodziców-twórców”, że wykonane są z bezpiecznych i nietoksycznych substancji, brakuje informacji o braku szkodliwości 
dla zdrowia materiałów, z których sztuczne dzieci są wykonane. Na niektórych rebornach widnieją ostrzeżenia, że są one wyłącznie lalkami kolekcjonerskimi, nie są zatem przeznaczone dla dzieci. Dla kogo produkowane są więc sztuczne niemowlęta? Jak mówi w wywiadzie Binczewska:

Tak jak chłopcy od zarania dziejów marzyli o idealnych modelach samochodów, tak dziewczynki marzą o lalkach, które przypominają dzieci. To jest rzeczywiście niezmienna rzecz, a jest w człowieku jakaś taka pogoń za naturą, tutaj fascynacja niemowlęctwem, i myślę, że to tak wszystko składa się w jedno. Ja uważam, że to są lalki dla dzieci, które mają jakiś tam również cel edukacyjny, bo one wyglądają jak dzieci, niemowlę jest zawsze ładne dla swojej mamy, jest ładne takie, jakie jest ${ }^{1}$.

Dzieci faktycznie zdają się idealnymi konsumentami rebornowych usług, gdyż na liście wymarzonych prezentów na Boże Narodzenie w 2009 roku lalki reborn znalazły się tuż po lalkach Barbie, a ceny „sztucznych dzieci” na serwisach aukcyjnych gwałtownie wzrosły. Na początku 2011 roku za dobrze wykonanego „sztucznego niemowlaka” trzeba zapłacić od 1600 do 2000 złotych. Pozostaje jednak pewna wątpliwość, czy w tym symulowanym świecie można oddać dziecku „do adopcji” inne dziecko? I na ile bezpieczną zabawką są lalki nieposiadające żadnych atestów, za to wyglądające jak sklonowane martwe noworodki? Jaki sens edukacyjny ma kupowanie dziecku tego typu lalki? W Stanach Zjednoczonych lalki służą głównie dorosłym, w filmie Moje sztuczne dziecko są prezentowane kobiety kupujące „niemal realne” niemowlęta, kobiety bezdzietne symulują macierzyństwo poprzez zabawę rebornem. Jedna z najbardziej znanych plastyczek tłumaczy motywy wykonywania tej specyficznej pracy rozmawiającej z nią dziennikarce:

Większość osób nie wie, że patrzy na lalkę. Nie można się nie zachwycić i nie powiedzieć, jakie cudowne nieprawdaż [...] Ludzie zwykle kupują ubranka dla dzieci, ponieważ one pasują na lalki. Czasami ludzie przesyłają do nas zdjęcia dziecka i my reprodukujemy takie dziecko, w taki sposób jak malarz maluje portret. Ta praca polega na stworzeniu pięknej lalki, takiej, która wywoła reakcję dla mnie to po prostu sztuka, którą tworzę 2 .

Zauważa ponadto, iż praca w domu ułatwia jej opiekę nad własnymi realnymi dziećmi... Pomimo deklarowanych pasji twórcy nie do końca bawią się tworzywem, wybierają rzeczywistość macierzyństwa realnego niesymulowaną, a symulacja staje się intratnym źródłem zarobkowania.

\footnotetext{
${ }^{1}$ http://dziendobrytvn.plejada.pl/24,18205,wideo,,91278,reborn_baby_po_polsku,aktualnosci_detal.html

2 Ibidem.
} 


\section{Idealne dziecko, jego rodzice i rzeczywistość symulowana}

Społeczeństwo ponowoczesne to społeczeństwo obfitości, dobrobytu, nadprodukcji (Baudrillard, 2006: 7), w którym obowiązuje swoisty przymus „bycia szczęśliwym za wszelką cenę" (Melosik, 2007: 47) i osiągania sukcesu we wszystkich sferach życia: materialnej, zawodowej, rodzinnej itp. Sukces życiowy ma tu charakter mierzony ilością i jakością zdobytych dóbr materialnych, a posiadanie rodziny i udanego (pięknego) dziecka postrzegane jest jako jedno z dóbr. Życie w ciągłej pogoni za luksusowymi towarami wymagającymi wysokich nakładów finansowych, dążenie do własnej wygody, indywidualnej kariery, życia bezproblemowego, zapewniającego maksymalny komfort, nie sprzyja rodzicielstwu, choć zachęca do korzystania z jego uroków: kołysania noworodka, kupowania ubranek dziecięcych, spacerów w piękną pogodę ze słodkim maleństwem grzecznie śpiącym w modnym wózku, i możliwości odłożenia rodzicielstwa na „później”, gdy konsumentka bądź konsument zacznie odczuwać znużenie czy nudę dotychczasowym życiem, bądź niepodejmowania realnego rodzicielstwa. W takiej sytuacji rodzicielstwo symulowane zdaje się idealnym rozwiązaniem, a zakup symulakry dziecka dobrym pomysłem. Nierzeczywiste dziecko nie choruje, nie brudzi ubrań, nie śmieci, nie zakłóca ciszy i harmonii domowego ogniska, a jego wygląd i płeć można dowolnie wybrać i zamówić za odpowiednią opłatą. Na internetowej aukcji eBay napotkałam na następujący opis „proponowanej do adopcji dziewczynki":

Maleńka Jasmine urodziła się: 1 grudnia 2009 roku o godzinie 23:10. Jej waga wynosi: 2050 g, a mierzy około $52 \mathrm{~cm}$. Maleństwo do złudzenia przypomina prawdziwe niemowlę. Posiada fałdki, kolor skóry, widoczne żyłki jak prawdziwe dziecko, a nawet otwarte dziurki w nosku. Włoski są naturalne i mięciutkie, wszczepione ręcznie po 1-2 w każdy otwór. Paznokietki pomalowane są specjalnym żelem. Cały brzuszek wykonano $\mathrm{z}$ wypełnionego materiału, a reszta $\mathrm{z}$ bardzo miękkiego soft winylu, co powoduje, że laleczka na rękach układa się jak żywe niemowlę! Jasmine pachnie jak maleńkie dziecko. Do nowej mamusi pojedzie z dużą wyprawką, ubranka, maskotka i magnetyczny smoczek - wszystko widoczne na zdjęciach. Jasmine na całym ciałku ma prześliczne fałdki, a na rączkach i nóżkach ma linie papilarne. Mała Jasmine czeka na nową rodzinę. Maleńka dziewczynka posiada także świadectwo narodzin ${ }^{3}$.

Inny niemowlak - tym razem „urodzony” w Polsce - reklamowany był w sposób równie interesujący, choć nieco infantylnym i pompatycznym językiem:

Mikołaj urodził się 22 maja 2007 roku, waży 2,48 kilograma, mierzy 57 centymetrów. Mikołaj pojawił się na świecie dzięki swojej pierwszej mamusi - artystce, która przez wiele dni wykonywała ręcznie proces reborn, dbając o każdy najdrobniejszy szczegół wyglądu maleństwa, tak

\footnotetext{
${ }^{3}$ http://cgi.ebay.pl/Niesamowicie-realistyczne-niemowle REBORN_W0QQitemZ160387299421 QQcmdZViewItemQQptZLH_DefaultDom
} 
by Mikołaj mógł wyglądać jak prawdziwy noworodek. Poddając Mikołaja procesowi reborn, artystka wykonała ręcznie: wszczepiane delikatnych, moherkowych rzęsek, połączenia główki, rączek i nóżek z brzuszkiem. Całe ciałko Mikołaja wykonane jest z jednego z najlepszych gatunkowo materiałów - pięknie pachnącego real touch vinylu. Materiał ten jest mięciutki i bardzo miły w dotyku, doskonale imitując ciałko prawdziwego bobaska. Wsadzanie pięknych, delikatnych włosków wykonanych z najlepszej odmiany moherku w kolorze jasnego, miedzianego brązu w otwory w główce maluszka - jest to zajęcie bardzo pracochłonne, ponieważ w jedną dziurkę wsadzanych jest zaledwie kilka włosków. Całe jego delikatne ciałko, jak również każda maleńka fałdka, zostały pomalowane kilkoma warstwami doskonałej jakości farbek Genesis. W rezultacie koloryt ciałka Mikołaja idealnie imituje pigment skóry prawdziwego niemowlęcia. Po zakończeniu tego zabiegu jego ciałko zostało zabezpieczone substancją chroniącą ją przed działaniem promieni UV, tak, by było zawsze piękne i nieskazitelne. Paznokietki u rączek i nóżek Mikołaja zostały pomalowane przepięknie żelem oraz dodatkową przezroczystą warstwą lakieru zabezpieczająca paznokietki przed łamaniem czy utratą połysku. Usteczka Mikołaja zostały misternie pomalowane błyszczącą farbką, tak by wyglądały na zwilżone. Całe ciałko Mikołaja może być dowolnie układane - jego rączki, nóżki oraz główka są ruchome. Mikołaj przybędzie do swojej nowej mamusi wraz z cudownym komplecikiem, w skład którego wchodzą: przepiękny rampersik z USA firmy Carter’s w kolorze błękitnym z aplikacją puszystego zwierzątka, biały pampers w niebieskie paski, letni komplecik z USA firmy Cutie Pie, słoneczna bluzeczka z krótkim rękawkiem, majtusie, rękawiczki-niedrapki, czapeczka na główkę, magnetyczny smoczuś z przypinką, piżamka, cudowne, misternie wykonane ręcznie buciki z różyczkami i koronką, skarpetusie, słodka czapeczka z błękitną tasiemką, akt urodzenia ${ }^{4}$.

Podobne opisy towarzyszą innym aukcjom.

\section{Spektakl niemal idealny w magicznej przestrzeni publicznej}

George Ritzer zauważał, iż w magicznym świecie konsumpcji istotne jest umagicznianie rzeczywistości za pomocą spektaklu nazwanego tu feerie. Feerie to - inaczej „niezwykłe widowisko o tematyce fantastycznej przedstawiające urojony świat za pomocą środków technicznych lub utrzymywany w podobnym stylu czy wnętrzu" (Ritzer, 2001: 183). Rodziny adoptujące małego reborna tworzą spektakl życia rodzinnego niemal tak realny, że same zdają się zatracać w tym pozorowanym świecie. W filmie pt. Moje sztuczne dziecko pokazane jest młode zamożne małżeństwo: kobieta - matka kilkorga rebornów urząaziła im pokój, nabywa luksusowe ubranka, kołysze w wózku na spacerach w parku, mężczyznę - ojca (?) nierzeczywiste dzieci zdają się nie obchodzić, ma własną kolekcję motorów i obcowanie z nimi zdaje się wystarczać mu do pełni szczęścia. Zabawę żony kwituje słowami: „Ja mam

4 Opis aukcji pochodzi z tekstu R. Majchrzaka Plastikowe dzieci i brzuchy z gipsu http://wiadomosci.o2.pl/?s=513\&t=9433 (dostęp 12.07.2012). 
swe motory, ona ma lalki”; pomimo doskonałych warunków materialnych i lokalowych realnym rodzicielstwem para nie wydaje się zainteresowana. Kiedy jedno z zamówionych „sztucznych dzieci” ma nieco uszkodzoną (pękniętą z tyłu, co nie przeszkadza w użytkowaniu) główkę, kobieta, mimo deklarowanego przywiązania i oczekiwania (proces przyjęcia reborna przypomina oczekiwanie na prawdziwe dziecko), odsyła go do producentki. Skojarzenie widza jest jednoznaczne: można odetchnąć z ulgą, iż nie narodziło się realne niepełnosprawne dziecko, gdyż - jak zaznacza użytkowniczka reborna zwana tu mamą - nie potrafiłaby ona zaakceptować żadnej wady „doskonałego dziecka”. W opiece nad „wnukami” pomaga jej matka (babcia rebornów), zwłaszcza gdy na świat przychodzą młodsze dzieci. Poród odbywa się w hotelu, gdzie obie kobiety czekają na paczkę z „noworodkiem” i zdaje się, niczym poród realny, wyczerpywać matkę fizycznie i psychicznie. Ten fikcyjny rodzinny świat jest tak realny, że granica pomiędzy tym, co wyobrażone, a co realne, przestaje istnieć. Zaabsorbowanej obowiązkami macierzyńskimi kobiecie pomaga jej matka, ojciec przyjmuje postawę wycofującą, rodzina wielodzietna, dobrze sytuowana materialnie, mieszka w dużym, pięknie urządzonym domu z ogrodem, sąsiedzi zachwycają się sztucznym noworodkiem, sami posiadają własne dzieci, także sztuczne. Tyle, że ta rzeczywistość nie istnieje. Czy komuś jednak to przeszkadza? Na jednym ze zdjęć zamieszczonym na aukcji widać dziecinny pokój, na środku stoi malutki stolik i odsunięte krzesło, jakby przed chwilą wstało z niego dziecko, na stoliku leży kartka z bloku i niedbale rozrzucone kredki. Obok stoi pięknie ubrana, uśmiechnięta dziewczynka z ciemnymi lokami. Widać, iż wychowuje się w szczęśliwym domu, pełnym miłości mamy i taty. Jedyne, co może zakłócać tę rodzinną sielankę, to fakt, że dziewczynka nie jest prawdziwym, lecz sztucznym dzieckiem. Czy taka rodzina kogoś szokuje? czy stanowi kolejną formę współczesnej ponowoczesnej rodziny? W Stanach Zjednoczonych zabawa rebornami jest popularna, $w$ tej symulacji uczestniczą symulowani rodzice, dziadkowie, sąsiedzi, ekspedientki. Na innym zdjęciu z aukcji sztuczne dziecko w pięknym ubraniu bawi się w ogródku nieopodal huśtawki, dobrze sytuowana pełna heteroseksualna rodzina, wychowuje niemal idealną córkę, a że nierealną?... Znajomi mają podobne dzieci, starsze panie pokazane na filmie umawiają się do parku na spacery, karmią sztuczne niemowlęta butelkami, tulą je, trzymają na kolanach, zachęcają do wspólnej zabawy w celu „naturalnej socjalizacji”. Rodzice rebornów są przy tym doskonałymi konsumentami, nabywają towary droższe niż realni rodzice, gdyż nie ponoszą innych wydatków związanych z wychowaniem dzieci (np. finansowaniem opiekunek, edukacji itp.), rebornowy biznes działa. Dla sztucznych

5 Moje sztuczne dziecko (My Fake Baby), reż. Victoria Silver, film dokumentalny emitowany 24 listopada 2008 roku na Zone Club. 
dzieci są wytwarzane kolekcje ubrań, mebli, butelki i smoczki, choć można też korzystać z rekwizytów dziecięcych. Na filmie ekspedientka w sklepie z odzieżą dziecięcą pomaga kobiecie wybierać ubrania dla malucha, polecając te najdroższe, firmowe: warto je kupić, bo maluch przecież z nich nie wyrośnie ani ich nie zniszczy. Klientka, niezależnie od swych „dziwactw”, jest kobietą luksusową, posiada gotówkę, karty kredytowe, napędza magiczny świat konsumpcji, warto zatem ją starannie obsłużyć i zachwycić się urodą dziecka. Symulowani rodzice wychowują symulakry dzieci w symulowanym społeczeństwie pełnym symulowanych interakcji. Czyżby futurystyczne przewidywania J. Baudrillarda, że rzeczywistość tak naprawdę nie istnieje (Baudrillard, 2006: 5) zdawały się prawdą? Prawdę mówiąc - pisze G. Ritzer

[...] tak wiele naszych kontaktów z ludźmi w owych miejscach (i poza nimi) ma charakter symulacji i tak się do tego przyzwyczailiśmy, że nie wiemy, co to jest "prawdziwa interakcja». W końcu wszystkie nasze interakcje są symulowane. Wszelkie różnice między symulowanym a prawdziwym w gruncie rzeczy się zatraciły, interakcja symulowana jest rzeczywistością (G. Ritzer, 2001: 198).

Nie wszystkie rodziny wychowujące „sztuczne dzieci” nie posiadają dzieci naturalnych, niektóre z rebornów mają rodzeństwo i są traktowane jako kolejne najmłodsze dziecko $\mathrm{w}$ rodzinie. Jedna z producentek plastyczek zaprezentowanych na filmie ma kilkoro własnych dzieci i sztucznego noworodka. Przemieszczając się samochodem, dzieci siedzą skulone na tylnym siedzeniu, by ich młodszy sztuczny braciszek wygodnie jechał w niemowlęcym foteliku. Jest przecież „żywą" reklamą pracy ich matki, która zapewnia dostatnie życie całej rodzinie. Symulakra żyje w symulacji, zapewniając możliwość przetrwania samej symulacji tworzącej symulakrę. Świat nierzeczywisty zdaje się bardziej rozrywkowy i spektakularny, nie ogranicza, jedynie dostarcza rozrywki i satysfakcji. Kolejna zaprezentowana w filmie młoda mama jest kobietą sukcesu - robi zawodową karierę, rozwija się, brakuje jej czasu na życie rodzinne, a tym bardziej macierzyństwo. Kupuje więc rebornowego noworodka, jak wyjaśnia - macierzyństwo zapewnia jej społeczny prestiż, a kobiety bezdzietne bywają wykluczane z życia społecznego. W jej przypadku „chwilowe” macierzyństwo zdaje się doskonałym rozwiązaniem na dopełnienie idealnej wizji życia i zapewnieniem sobie wysokiej pozycji społecznej. Chcąc odpowiedzieć na pytanie, dlaczego w wielu krajach nierealne rodzicielstwo staje się popularne, odwołać się można do myśli G. Ritzera, pisze on: „Chyba najważniejszym powodem tworzenia symulacji, czyli przekształcania zjawisk "prawdziwych» w imitację, jest to, że mogą one być bardziej widowiskowe od ich autentycznych odpowiedników, a zarazem bardziej atrakcyjne dla konsumentów" (G. Ritzer, 2001: 200). 


\section{A jak się znudzi, pójdzie w kąt... - przeżywanie przyjemności rodzicielstwa i wolność od dziecka}

Społeczeństwo ponowoczesne cechuje życie chwilą, niemożność zaspokojenia potrzeb związanych z przeżywaniem przyjemności, gdyż po chwili pojawiają się nowe potrzeby, ulotność czasu, kolekcjonowanie wrażeń i emocji. Jak pisze Zygmunt Bauman: „Przeżycie, o które chodzi, nie dotyczy ciała konsumenta czy jego społecznej tożsamości, lecz właśnie samego pragnienia, to pragnienie tworzy konsumenta, konsumujące pragnienie konsumowania" (Bauman, 2006: 219). Symulowane rodzicielstwo może być - w odróżnieniu od realnego - rodzicielstwem krótkotrwałym, nie kolidującym z obowiązkami zawodowymi, życiem towarzyskim czy atrakcyjnym spędzaniem czasu wolnego na zagranicznych wojażach. Pozostawiony samotnie reborn nie wymaga opieki, pielęgnacji i troski, można go zamknąć w pięknym dziecięcym pokoju i... odkurzyć, gdy będzie potrzebny, lub sprzedać innej parze krótkotrwałych rodziców, ewentualnie wymienić na inny model np. starszej lalki, sugerując tym samym, iż dziecko dorasta, nie zostając oskarżonym o zaniedbanie i poddanym moralnej restrykcji społecznej za egoizm. Znudzeni płcią dziecka rodzice mogą zamienić dziewczynkę na chłopca (lub odwrotnie), blondyna na bruneta, kupić dziecko o orientalnych rysach czy ciemnym kolorze skóry. Prawdopodobnie z tej przyczyny na internetowych aukcjach zakupić można używane „sztuczne dzieci” w stanie niemal idealnym, wraz ze świadectwem urodzin i kolekcją eleganckich ubrań. Pewne modele rebornów stają się przy tym niemodne, niczym przestarzały model butów czy sukienek. Dążąc do bycia na topie, bycia „trendy”, wymagają rozwiązania procesu adopcji i szybkiej wymiany, by nie stracić prestiżu i pozycji w gronie rebornowych rodziców. Napędza to proces konsumpcji i zapewnia plastykom godziwe środki do życia. Rebornowy biznes rozkręca się, wzmagając konkurencję.

„Trzeba «produkować» wysokim kosztem coraz to nowych konsumentów, którymi kieruje pragnienie. I w rzeczy samej, produkcja konsumentów pożera ogromną część całkowitych kosztów produkcji, dystrybucji i handlu. Część, którą konkurencja jeszcze bardziej rozdyma” (Bauman, 2006: 213) - zauważa Bauman. A dokonany przez niego tak trafnie opis procesu konsumpcji pozwala wytłumaczyć, dlaczego modele sztucznych dzieci wciąż są udoskonalane, by były bardziej realne, czasem nawet zbyt realne. Przekonali się o tym policjanci z Queensland z Australii, którzy wybili szybę w samochodzie stojącym na parkingu, gdyż zauważyli w foteliku nieprzytomne niemowlę; to jednak okazało się przy bliższym oglądzie sztuczne. W Poznaniu przejęty starszy pan zdenerwował się, iż mała dziewczynka trzymała na ręku niemowlę, zwrócił uwagę matce, by dowiedzieć się, że niemowlę jest pięknym modelem reborna (Sobańska, 2009). 
Sztuczne dzieci pozwalają - w pewnym stopniu - cieszyć się możliwością opieki nad noworodkiem i wolnością od tej opieki jednocześnie. Umożliwiają uzyskanie statusu rodziny poprzez jej symulację i zapewniają społeczny prestiż wynikający $\mathrm{z}$ posiadania dziecka. Jedna $\mathrm{z}$ kobiet $\mathrm{w}$ filmie słusznie zwraca uwagę, że macierzyństwo kobiety zapewnia jej szacunek, akceptację i uznanie ze strony bliskich osób ${ }^{6}$, bezdzietność budzi podejrzenia, posądzenie o bezpłodność, co bywa dla wielu kobiet faktem bolesnym. Sztuczne dzieci wyglądają zaś tak realistycznie... Niektóre z pokazanych par małżeńskich zdecydowanie nie byłyby w stanie wziąć odpowiedzialności za realnie żyjącego noworodka ze względu na brak dojrzałości emocjonalnej, zaburzenia charakterologiczne, brak psychicznej równowagi. Inne szukały wyłącznie przyjemnościowego aspektu posiadania dziecka, uciekając od odpowiedzialności wynikającej z rodzicielstwa. Może zatem w tych przypadkach wybór „sztucznych dzieci” był niemal idealnym rozwiązaniem? Zużyta, przestarzała lalka sprzedana na internetowej aukcji to w końcu nie porzucone czy zaniedbywane ludzkie niemowlę...

\section{Terapia i wychowanie poprzez symulakry i symulację? - konkluzja}

Producenci lalek reborn zdają się nie widzieć problemu dotyczącego sposobu ich użytkowania, gdyż wytwarzanie i sprzedaż lalek zapewnia im utrzymanie. Zresztą nie w samej lalce tkwi przecież problem, lecz w tym, iż sztuczne dzieci idealnie wkomponowały się w lukę w społeczeństwie ponowoczesnym, gdzie ludzkim instynktom do prokreacji i opieki nad dzieckiem przeciwstawiono dążenie do konsumeryzmu, wygodnej, łatwej i bezproblemowej egzystencji. Społeczność ludzka w ostatnich latach zdołała się już przyzwyczaić do gumowych kochanek i kochanków z sexshopów, plastikowych i lateksowych odlewów rąk, nóg i części intymnych służących zabawie lub dostarczaniu rozkoszy, interaktywnych psów i kotów, niemal realnych wirtualnych gier komputerowych symulujących realne życie, portalowych przyjaźni i miłości. Naturalną koleją rzeczy zdaje się pojawienie się „sztucznych dzieci”. Twórczyni rebornów Magdalena Binczewska wielokrotnie w wywiadzie podkreśla, iż tworzy lalki dla dzieci i przypisuje im walory edukacyjne. Mówi ona: „Te lalki wywołują uczucia macierzyńskie i uczą dzieci opieki nad niemowlęciem"7. Wyraźnie ignoruje dane pochodzące ze Stanów Zjednoczonych, Anglii i Kanady dotyczące użytkowników „sztucznych lalek”, jak i zastrzeżenia

\footnotetext{
${ }^{6}$ Ibidem.

${ }^{7}$ http://dziendobrytvn.plejada.pl/24,18205,wideo,,91278,reborn_baby_po_polsku,aktualnosci _detal.html (dostęp 12.07.2012).
} 
pochodzących stamtąd plastyczek, iż nie są to lalki dla dzieci i nie powinny być dzieciom dawane (choćby $\mathrm{z}$ powodu braku informacji o potencjalnym wpływie na zdrowie składników, z których są wykonane). Trudno pojąć, skąd bierze się jej przekonanie, że w Polsce nabywcy (mamusie) lalek (dzieci) wykażą się nieco większą logiką i przywiązaniem do rzeczywistego świata niż we wspomnianych krajach. O tym, iż nie jest to „towar” polecany dzieciom, jednoznacznie świadczą przytaczane przeze mnie w początkowej części tekstu opisy lalek zamieszczane na internetowych aukcjach, a także podziękowania przychodzące do oddających dzieci do adopcji „biologicznych mamuś” (czyli artystek). Deborah King przytacza podziękowania, jakie dostaje od szczęśliwych „rodziców”:

Witaj. Moja nowa córeczka dotarła już do domu. Jest urocza i wspaniała. Ma piękną poduszeczkę i słodkie zabawki. Jestem Ci bardzo wdzięczna. Nie wiem tylko, kiedy wyślę Ci jej pierwsze zdjęcie z nowego domu, bo jak na razie nie umiem obsługiwać aparatu cyfrowego ${ }^{8}$.

Jaime Eaton, pytana przez dziennikarzy, czy zdaje sobie sprawę, że żeruje na zaburzeniach psychicznych swoich klientek, odpowiedziała, że nie zastanawia się nad tym, co kobiety robią ze swoimi lalkami, ona zaś zarabia na ich sprzedaży. Sama jednak zdaje się kompensować sobie niemożność posiadania większej liczby własnych dzieci, gdyż po czterech cesarskich cięciach nie mogła po raz kolejny zostać matką. Zaznacza, że lalki są jej lekiem na cierpienie, a ona sama płacze, oddając je do adopcji (Chądzyńska, 2008), od rodziców zaś otrzymuje listy wyrażające zachwyt nad jej małymi dziełami sztuki. Oto jeden z nich: „Kiedy zobaczyłam Theo i Daffodil, rozpłakałam się. Wyglądały jak żywe. Nie mogę się doczekać, kiedy zacznę kupować dla nich ubranka. Niedługo zabieram je do rodziców (dumnych dziadków - dopisek D.Z-N). Jestem ciekawa ich reakcji” (Chądzyńska, 2008). Podobne listy także otrzymuje M. Binczewska: „Ona leży otulona w swoim koszyczku przy moim komputerze (żebym mogła sprawdzić, czy płacze). Dziękuję bardzo za zrobienie takiej słodkiej, kochanej dziewczynki" (Sobańska, 2009). W omawianym filmie wspomina się o możliwości kompensacji straty dziecka $\mathrm{w}$ wyniku poronienia poprzez kupno maleńkiego reborna. Wówczas to - zdaniem autorów filmu - rodzice tworzą świat symulowany, zamiast utraconego dziecka wychowując symulakrę i łatwiej znoszą rozstanie. Mówi się też o możliwości adoptowania sztucznego dziecka przez pary bezdzietne nie mogące płodzić dzieci. W ten sposób można tworzyć całą symulowaną społeczność, a bezdzietne pary wychowujące maleńkie reborny mogą spotykać się z innymi rodzicami rebornów... $Z$ perspektywy psychologów zachowanie to oceniane jest jako pogranicze normy i patologii. Maria Beisert, psycholog, seksuolog, kierow-

8 Jak sobie zrobić sztuczne dziecko? http://www.dziennik.pl/kobieta/dziecko/article209433/Jak_ sobie_zrobic_sztuczne_dziecko_.html (dostęp 12.07.2012). 
nik Pracowni Seksuologii Społecznej i Klinicznej w Instytucie Psychologii UAM w Poznaniu na pytanie o terapeutyczne oddziaływanie lalek odpowiada:

Dzieło sztuki jest do podziwiania. W tym przypadku można mówić raczej o pewnego rodzaju imitacji dziecka. Taka lalka zachowuje stały obraz, który burzy się wraz z dorastaniem dziecka. Jest to personifikacja martwego przedmiotu, która dąży do uznania martwej rzeczy za żywą. W ten sposób balansuje się między dopuszczalnym zachowaniem a patologią (Sobańska, 2009).

Jej zdaniem szczególnie niebezpieczne jest proponowanie kupna lalek rodzicom, którzy stracili dziecko w wyniku poronienia, gdyż zaburza to lub odnawia naturalny proces żałoby, oraz parom niemogącym mieć dzieci. Takie kobiety pozornie tylko skompensują sobie niemożność posiadania potomstwa, gdyż lalka nie zastąpi realnego dziecka, pozostanie pustka, brak dwustronnej interakcji (Sobańska, 2009). Można też sądzić, iż zniechęci potencjalnych nabywców do adopcji realnego dziecka lub tworzenia rodzin zastępczych. Pewną wątpliwością, którą zgłaszają użytkownicy forów internetowych, gdzie dyskusje na temat rebornów są dość częste, jest możliwość wykorzystywania lalki przez pedofilów, z drugiej jednak strony, jeśli ograniczą oni swą aktywność do obcowania płciowego z lalką (co chroniłoby przed atakami z ich strony realne dzieci), być może byłoby to zjawisko pozytywne. Czy można mówić o konstruktywnym zastosowaniu lalki reborn? Z pewnością tak, jeśli zostanie wykorzystana jako przedmiot kolekcjonerski (dzieło sztuki), w celu edukacyjnym w szkołach rodzenia czy jako manekin prezentujący kolekcję odzieży dziecięcej. Takie zastosowanie lalek również ma miejsce w Polsce - na co zwraca uwagę M. Binczewska.

\section{Literatura}

Baudrillard J. (2005). Symulakry i symulacja. Warszawa

Baudrillard J. (2006). Społeczeństwo konsumpcyjne - jego mity i struktury. Warszawa

Bauman Z. (2006). Społeczeństwo w stanie oblężenia. Warszawa

Chądzyńska A. (2008). Ona zrobi ci dziecko. „Przekrój” nr 25

http://cgi.ebay.pl/Niesamowicie-realistyczne-niemowle REBORN_W0QQitemZ160387299421

QQcmdZViewItemQQptZLH_DefaultDom (dostęp 20.03.2011)

http://dziendobrytvn.plejada.pl/24,18205,wideo,,91278,reborn_baby_po_polsku,aktualnosci_ detal.html (dostęp 20.03.2011)

Foucault M. (2009). Nadzorować i karać. Narodziny więzienia. Warszawa

Jaksobie zrobićsztuczne dziecko? (2011). http://www.dziennik.pl/kobieta/dziecko/article209433/

Jak_sobie_zrobic_sztuczne_dziecko_.html (dostęp 20.03.2011)

Majchrzak R.(2011).Plastikowedzieci ibrzuchyzgipsu. http://wiadomosci.o2.pl/?s=513\&t=9433 (dostęp 20.03.2011)

Melosik Z. (2007). Teoria i praktyka edukacji wielokulturowej. Kraków 
Moje sztuczne dziecko (My Fake Baby). Reż Victoria Silver, film dokumentalny emitowany 24 listopada 2008 roku na Zone Club.

Ritzer G. (2001). Magiczny świat konsumpcji. Warszawa

Sobańska E. (2009). Dla kogo pociecha z lalki? „Polska. Głos Wielkopolski” 17 sierpnia 2009. http://www.binczewska.pl/pliki/gw.pdf (dostęp 20.03.2011)

\section{Adult Girls and Their Little Dolls - Reborns in the Postmodern Culture}

\section{Summary}

In her paper "Adult Girls and Their Little Dolls - Reborn in the Postmodern Culture", Dr Dorota Zaworska-Nikoniuk deals with a problem which has recently become rather conspicuous in the Polish postmodern reality. The author refers to the image of modern maternity, which she describes in the context of possessing a "tailor-made" child. In the first part of her paper, she brings up the issue of the reborn doll business, and she mentions a Polish artist who creates dolls resembling human babies wit as much realism as possible. In the United States, reborn dolls first appeared in the 1990s, and soon became very popular in other Western countries, as well as in Poland. M. Binczewska, an artist to whom the author refers several times in her paper, presented her works at the MTP Festival of Artistic Objects, where they aroused a deep interest. The author describes the process of creating fake babies, reborn dolls, using provoking and philosophical questions since, as she notes, the demand for "live dolls" is big, and they have been generating ever- increasing interest. In numerous interviews, manufacturers of reborn dolls stress that they make only a marginal profit, as the manufacturing costs are very high. However, the author is very sceptical about artists claiming that they can earn only a small profit on reborn dolls, and she suspects that this is merely an elaborate manipulation on their part, intended to win new potential buyers; when realising their artistic visions, they simply meet their customers' needs. Their products, however, stimulate such needs. The author speaks of "an ongoing process of the doll's birth"; in this peculiar simulation manufacturers take control over the language, attempting to persuade the users that when they buy the doll, they will become parents. Paraphrasing the concepts of M. Foucault, it is possible to say that they take control over the language to impose the knowledge of the consumer's reality, in this particular case creating human needs and desires." The idea of creating the reality and playing at being God is both the paper's keynote and a rhetorical question, intended to draw attention to the disturbed and pathological process of creating contemporary reality by satisfying consumers' everyday needs. The author quotes a number of ads for sale of reborn dolls, placed on the Allegro and eBay websites, emphasising the calculated attitude of manufacturers or owners of such dolls to prospective buyers. Based on the theories of J. Baudrillard, she comments on this in the following way: "A consumerist society is characterised not only by an abundance and easy availability of goods and services, but also by something much more important - the fact that everything is a form of service. What is consumed is never seen as an ordinary product but as a kind of personal favour or gratification". Contemporary manufacturers of reborn dolls perfectly fit into this gloomy reality, attributing to their works not only an artistic value but also an educational and therapeutic one. M. Binczewska ascribes to her simulacra educational qualities, and she stresses that such a strong resemblance of the dolls to real babies may inspire children to look 
after younger persons and, in the future, develop maternal instincts in them. However, the author of the article challenges the artist's theory, stressing that such dolls are not licensed for sale as toys for children since they do carry appropriate labels. In an interview, M. Binczewska mentions other uses of reborn dolls, treating them as collector's items for women - just as men have always been dreaming of ideal models of cars, ideal models of children are now available to women. But the reality is different. In practice, simulacra are bought by those women who, socially, want to be considered as mothers, but at the same time do not want to bear the costs thereof. The author mentions the film My Fake Baby, which tells the story of "fake mothers". According to her, none of those women who buy reborn babies have a sense of living in an unreal, dreamlike world. In the United States, whole local communities accept such a form of satisfying maternal needs. Grandmothers, neighbours and friends give their support to those who order and buy fake babies. But the product must always be ideal - with no flaws, and is has to fit the wishes of those who ordered it. Reborn dolls are normally "used" as real babies of wealthy parents, who can afford to buy the fanciest and most expensive clothes and gadgets. At first glance, one might assume that they are the happiest kids of loving parents; but they are not living beings. It is all about creating magical public space, an almost ideal spectacle, as Dr Zaworska-Nikoniuk notes in the next part of her article referring to G. Ritzer who claims that in the magical world of consumption, reality needs to have all the hallmarks of magic as well. "Families adopting little reborn dolls stage a 'family life' spectacle, which is so realistic that they themselves seem to become completely engrossed in this fake world." The world of such constructed and being constructed reality is an arena for making money. But is it only this? It also offers space for a new form of interpersonal communication in which hypocrisy is evident, in which fake parents are viewed by shop assistants and passers-by as real parents - or even parents who are better than the real ones. The author wonders whether "[...] J. Baudrillard's futuristic predictions that reality does not really exist have come true?" To tell the truth - writes G. Ritzer - "[...] so often our contacts with other people in those places (and beyond them) are simulated, and we have become so much accustomed to this, that we do not know what 'real interaction' is. In any case, all our interactions are simulated. In actual fact, all differences between what is simulated and what is real have almost disappeared - simulated interaction is a reality." It is a grim reality, where the line between "the real I" and "the ideal I" is blurred, where to achieve success is not tantamount to creating new values for society and oneself, but to creating new, unreal needs in such a way that the individual can always have a sense of being the best, at the same time being unaware that he/she is merely a puppet in a fools' arena. Such a conceptualisation of satisfying one's needs "here and now" renders unreal the institution of family in its traditional form. The child has always been a natural factor conducive to the process of cementing family ties - on the one hand giving a sense of personal fulfilment, but on the other hand presenting new challenges and motivation to make every effort to raise the family's standard of living. The author notes that to some extent reborn dolls make it possible to enjoy the opportunity to look after a newborn baby, while at the same being free from any duties such care might entail. They allow individuals to achieve the status of a family (a simulated one, in fact), enjoy greater social prestige and gain recognition from family and friends. Childlessness evokes suspicion (e.g., of infertility), which for many women is rather painful (as testified by those who appeared in My Fake Baby). Nowadays, instead of wrestling with a problem which inhibits an individual's personal development, more and more people decide to create a fake world and adapt their needs to it. Sadly, creating such a reality can lead to dangerous situations. The author gives examples of situations when police officers intervened to rescue a child, only to find out that the child was in fact a reborn doll. 
Manufacturers and consumers of fake babies do not see any need to make a fuss about this distorted reality. New buyers of reborn dolls send moving thank-you letters whose trivial and simple content makes a conscious reader reflect on the course of man's moral development. However, for the manufacturers they are merely a form of gratitude for all the effort they have put into creating fake babies. Not without reason, in the last part of her article the author wonders what influence a stimulated reality might have on the mentality of women and men. She quotes Professor M. Beisert, who claims that “(...) unlike real babies, such dolls do not change, whereas real children change as they begin to grow up. It is the personification of an inanimate object, aimed at recognising such an object as a living being. It is like balancing between acceptable behaviour and pathology". Concluding, the author wonders if the presence of reborn dolls on the market might possibly have any positive aspects, e.g. act as a deterrent, preventing paedophile behaviour exhibited towards real children, or as a collector's item or dummy. 
